\title{
Upamiętnienia
}





\title{
Zofia Wóycicka
}

Niemiecki Instytut Historyczny w Warszawie

https://orcid.org/0000-0002-9461-2387

woycicka@dhi.waw.pl

\section{Zachować decorum. Nowa ekspozycja stała w Muzeum i Miejscu Pamięci w Sobiborze}

\begin{abstract}
Streszczenie
Jesienią 2020 r. na terenie dawnego niemieckiego ośrodka zagłady SS-Sonderkommando Sobibor otwarto nową ekspozycję muzealną dokumentującą historię tego miejsca oraz upamiętniającą jego ofiary. Muzeum jest ulokowane w nowym, wybudowanym specjalnie w tym celu, minimalistycznym budynku. Wystawa ma charakter ściśle dokumentalny; bardzo oszczędnie korzysta z multimediów i wystrzega się wszelkich form inscenizacji historii, które kuratorzy uznali za niestosowne. Nie ma ona sztucznie eskalować emocji, ale ma stanowić miejsce „informacji, refleksji i żałoby”. Mimo swej prostoty jest niezwykle nowoczesna i podąża za światowymi trendami w dziedzinie upamiętnienia masowych zbrodni, $\mathrm{w}$ tym przede wszystkim zbrodni drugiej wojny światowej i Holokaustu.

Prezentacja opiera się na wiedzy pozyskanej podczas prowadzonych od 2000 r. prac archeologicznych. Pozwoliły one zweryfikować wiele informacji dotyczących topografii i historii obozu. Wydobyły również na światło dzienne tysiące artefaktów, które stały się trzonem nowo powstałej ekspozycji. Ma ona stanowić wprowadzenie do wizyty w miejscu historycznym i ułatwić zwiedzającym „czytanie zastanego krajobrazu”. Sam teren obozu czeka jednak jeszcze na uporządkowanie i upamiętnienie.
\end{abstract}

\section{Słowa kluczowe}

Sobibór, obozy zagłady, obozy akcji „Reinhardt”, muzeum, miejsce pamięci, zagłada Żydów

\begin{abstract}
In the fall of 2020 at the site of the former German extermination center SS Sonderkommando Sobibor a new permanent exhibition was opened documenting the history of this place and commemorating its victims. The museum is located in a new minimalist building erected specifically for this purpose. The exhibition has a strictly documentary character. It makes limited use of multimedia and abstains from staging history deemed inappropriate by the curators. It is not aimed at an artificial evocation of emotions. Instead, it was conceived as a place of "information, reflection, and mourning." Despite its simplicity, it is very modern and follows newest international exhibition trends, in particular those applied in WWII and Holocaust memorials and museums.

The presentation is based on new findings made during archeological excavations conducted since 2000, which allowed to verify our knowledge about the topography and history of the camp. They also brought to light thousands of artifacts, which became the center-pieces of the newly created display. The exhibition is intended to introduce visitors to the historical
\end{abstract}


site and to help them "read the landscape". However, the historical site itself still awaits to be ordered and commemorated.

\section{Key words}

Sobibór, extermination centers, Aktion Reinhardt camps, museum, memory site, Holocaust

W październiku 2020 r. na terenie dawnego niemieckiego obozu zagłady SS-Sonderkommando Sobibor otwarto nową ekspozycję muzealną poświęconą historii tego miejsca oraz upamiętniającą jego ofiary. Po Muzeum Kulmhof w Chełmnie nad Nerem jest to druga prezentacja muzealna powstała w ostatnich kilku latach, dokumentująca historię jednego z nazistowskich ośrodków eksterminacji działających na terenie okupowanej Polski. Podobnie jak Kulmhof, również Sobibor pozostawał przez wiele lat miejscem zapomnianym - „nie-miejscem pamięci"1.

Dopiero w połowie lat sześćdziesiątych teren dawnego obozu został częściowo uporządkowany i doczekał się skromnego upamiętnienia. Godne uwagi jest to, że opracowana wtedy przez Romualda Dylewskiego koncepcja upamiętnienia starała się uwzględniać topografię tego miejsca, która wyłaniała się z ówcześnie znanych świadectw i dokumentów ${ }^{2}$. Upamiętniono rampę kolejową; tam, gdzie - jak sądzono - znajdowały się mogiły z prochami pomordowanych, usypano kopiec; w pobliżu miejsca, w którym były komory gazowe, ustawiono pomnik w kształcie wieży-komina oraz rzeźbę matki z dzieckiem autorstwa Mieczysława Waltera. Dopiero jednak badania archeologiczne prowadzone od 2000 r. pozwoliły zweryfikować położenie poszczególnych elementów ośrodka eksterminacji, w tym masowych grobów, komór gazowych, krematorium oraz tzw. Himmelfahrtstrasse, czyli ogrodzonej drutem kolczastym drogi, którą ofiary pędzone były z Lager II (obozu II) na śmierć. Odkryto również ślady po tunelu wykopanym prawdopodobnie przez więźniów żydowskiego Sondekommando, zatrudnionych w Lager III (obozie III) przy paleniu ciał osób pomordowanych. Spośród więźniów tej części obozu nikt nie przeżył, a o nieudanych próbach

${ }^{1}$ Termin zapożyczyłam od Romy Sendyki i jej zespołu. Sendyka nawiązuje do określenia Claude'a Lanzmanna les non-lieux de la mémoire, odnoszącego się właśnie do nie-upamiętnionych, opuszczonych miejsc po dawnych nazistowskich obozach koncentracyjnych i zagłady (Roma Sendyka, Miejsca/nie-miejsca pamięci [w:] Nie-miejsca pamięci. Elementarz, red. Karina Jarzyńska, Maria Kobielska, Jakub Muchowski, Roma Sendyka, Aleksandra Szczepan, Kraków: Ośrodek Badań nad Kulturami Pamięci, 2017, s. 10, https://ruj.uj.edu.pl/xmlui/bitstream/ handle/item/49688/jarzynska_kobielska_muchowski_sendyka_szczepan_nie-miejsca_pamieci_elementarz_2017.pdf?sequence=1\&isAllowed=y, dostęp 9 VIII 2021 r.).

${ }^{2}$ Zwraca na to uwagę Tomasz Kranz: Upamiętnienie pomordowanych. Pomnik z 1965 r. $w$ hołdzie ofiarom obozu, „Varia. Magazyn/Magazine”, październik 2020 r. (numer specjalny), s. 35, http://www.sobibor-memorial.eu/pl/news/o_wystawie_stalej_w_sobiborze_w_magazynie varia/1392 (dostęp 6 VIII 2021 r.). 
ucieczki historycy wiedzieli dotychczas tylko z relacji z trzeciej ręki ${ }^{3}$. Oprócz tego na terenie dawnego ośrodka zagłady znaleziono około 11 tysięcy artefaktów, przedmiotów osobistych po zamordowanych, a także elementów struktury obozowej, narzędzi zbrodni i innych rzeczy należących do sprawców ${ }^{4}$.

W 2008 r. Polska, Holandia, Słowacja, tj. kraje, skąd pochodziło najwięcej ofiar obozu, oraz Izrael zainicjowały współpracę na rzecz upamiętnienia ofiar Sobiboru i utworzenia tam Muzeum-Miejsca Pamięci. W podpisanym w $2011 \mathrm{r}$. liście intencyjnym określono zasady współpracy, co wiązało się też z deklaracją gotowości do współfinansowania projektu ${ }^{5}$. W 2012 r. Sobibór, wcześniej oddział Muzeum Pojezierza Łęczyńsko-Włodawskiego we Włodawie, trafił pod kuratelę Państwowego Muzeum na Majdanku. Rok później ogłoszono i rozstrzygnięto międzynarodowy konkurs na koncepcję architektoniczno-artystyczną miejsca pamięci. Wygrał polski zespół w składzie: Marcin Urbanek, Piotr Michalewicz, Mateusz Tański (Biuro Architektoniczne RE: Michalewicz \& Tański) i Łukasz Mieszkowski ${ }^{6}$. Powołano również Międzynarodowy Komitet Sterujący, skupiający przedstawicieli Polski, Holandii, Słowacji i Izraela, który konsultował poważniejsze decyzje dotyczące formy upamiętnienia i kształtu ekspozycji muzealnej w Sobiborze. W wyniku negocjacji między członkami Komitetu zwycięska koncepcja upamiętnienia została zmodyfikowana, tak aby była zgodna $\mathrm{z}$ „tradycjami i normami” kultur pamięci wszystkich zaangażowanych krajów ${ }^{7}$. Konieczne było także uwzględnienie wyników prowadzonych nadal prac archeologicznych. Architekci zaprojektowali również budynek przyszłego muzeum.

${ }^{3}$ Sobibór - archeologia pamięci, Muzeum i Miejsce Pamięci w Sobiborze, 7 czerwca 2013 r., http://www.sobibor-memorial.eu/pl/news/sobibor____archeologia_pamieci/397 (dostęp 9 VIII 2021 r.).

${ }^{4}$ Aleksandra Szymula, Muzealia sobiborskie. Przedmioty znalezione $w$ miejscu zbrodni, „Varia. Magazyn/Magazine”, październik 2020 r. (numer specjalny), s. 38, http://www.sobibor-memorial.eu/pl/news/o_wystawie_stalej_w_sobiborze_w_magazynie___varia/1392 (dostęp 9 VIII 2021 r.).

${ }^{5}$ Memorandum of Understanding with regard to a collective project on to establish a Museum-Memorial Site within the area of the former Nazi German extermination camp Sobibor, 28 lutego 2011 r. https://archiv.vlada.gov.sk/ludskeprava/data/files/7401.pdf (dostęp 9 VIII 2021 r.).

${ }^{6}$ Marcin Urbanek, Piotr Michalewicz (Biuro Architektoniczne RE: Michalewicz \& Tański) oraz Łukasz Mieszkowski, Projekt upamiętnienia obozu zagłady w Sobiborze. I nagroda w Międzynarodowym Konkursie na opracowanie ideowo-artystycznej koncepcji architektoniczno-krajobrazowej miejsca pamięci na terenie Byłego Hitlerowskiego Obozu Zagłady w Sobiborze, https://www.polin.pl/template/gfx/sobibor.pdf (dostęp 5 VIII 2021 r.).

${ }^{7}$ Avner Shalev, Słowo od członków Międzynarodowego Komitetu Sterującego, „Varia. Magazyn/Magazine", październik 2020 r. (numer specjalny), s. 11, http://www.sobibor-memorial.eu/pl/news/o_wystawie_stalej_w_sobiborze_w_magazynie__varia/1392 (dostęp 9 VIII 2021 r.); Sobibór Gedenksteine/Miejsce pamięci, https://sobibor.de/pl/miejsce-pamieci/ (dostęp 5 VIII 2021 r.). Zmieniony projekt upamiętnienia: Michalkiewicz \& Co. Architects, $M u-$ zeum oraz miejsce pamięci ofiar na terenie byłego nazistowskiego obozu zagłady, http://www. michalewicz.co/Sobibor-commemoration (dostęp 5 VIII 2021 r.). 
Wiosną 2019 r. rozstrzygnięto konkurs na opracowanie koncepcji realizacji i aranżacji plastycznej wystawy stałej w Sobiborze ${ }^{8}$. Zwycięzcami konkursu są Jarosław Kłaput i Barbara Kłaput z „Kłaput Project” s.c. Koszty budowy budynku muzealnego zostały pokryte z dotacji Ministerstwa Kultury i Dziedzictwa Narodowego. Natomiast realizacja samej wystawy sfinansowana została z darowizny Republiki Federalnej Niemiec. Głównym kuratorem wystawy był Tomasz Kranz, dyrektor Państwowego Muzeum na Majdanku, a przy tworzeniu jej scenariusza współpracowali Dariusz Libionka oraz Krzysztof Banach. Na razie otwarto budynek muzeum z nową ekspozycją stałą. Prace nad całościowym upamiętnieniem terenu obozu ciągle trwają.

\section{Budynek muzeum i ekspozycja stała}

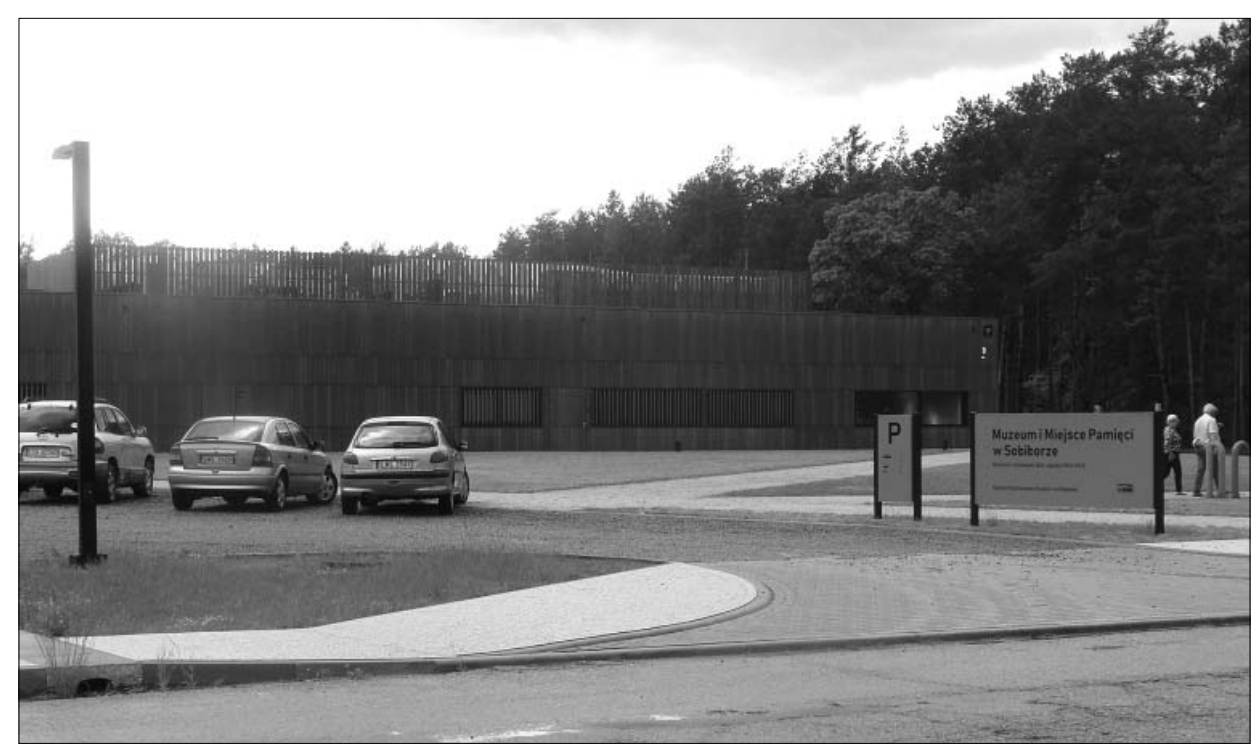

Nowo powstały, minimalistyczny budynek muzeum (fot. Zofia Wóycicka)

Muzeum ulokowane jest w parterowym, minimalistycznym budynku. Łączy on dwie, oddzielone w przestrzennej koncepcji upamiętnienia tego miejsca strefy: Lager III, czyli właściwy ośrodek zagłady, na którego terenie znajdowały się komory gazowe oraz masowe mogiły ofiar, oraz Lager I (obóz I), w którym przetrzymywani byli żydowscy więźniowie: mężczyźni i kobiety. Byli oni

\footnotetext{
${ }^{8}$ Rozstrzygnęliśmy konkurs na opracowanie koncepcji realizacji aranżacji plastycznej wystawy stałej w Sobiborze, Muzeum na Majdanku, 20 maja 2019 r., http://www.majdanek.eu/ pl/news/rozstrzygnelismy_konkurs_na_opracowanie_koncepcji_realizacji_aranzacji/1071 (dostęp 6 VIII 2021 r.).
} 
zatrudnieni przy sortowaniu mienia pomordowanych, do obsługi niemieckiej załogi obozu oraz $\mathrm{w}$ warsztatach rzemieślniczych, w których naprawiano i przerabiano zrabowane rzeczy. To tu 14 października 1943 r. wybuchł bunt, a w jego wyniku około 300 osobom udało się zbiec. Jak piszą autorzy projektu budynku muzealnego, jego „[d]wie szczytowe, szklane ściany otwierają się na dwa widoki, symbolizujące tragiczną odmienność losu więźniów. Widok przez szyby fasady północnej urywa się, zamknięty przez otchłań Himmelfahrtstrasse, drogi do komory gazowej [...]. Przez tafle fasady południowej otwiera się niezakłócona niczym panorama dawnego placu, na którym zaczął się bunt, i lasu, w którym schronili się uciekinierzy" mają więc „symbolicznie zaznaczać granice między śmiercią a wywalczoną przez część więźniów wolnością, kierując uwagę zwiedzających nie tylko na bocznicę kolejową i drogę prowadzącą do komór gazowych, lecz także na Lager I [...] miejsce wybuchu powstania"10.

Inaczej niż omawiana przeze mnie w poprzednim numerze pisma „Zagłada Żydów. Studia i Materiały" wystawa stała w Muzeum Kulmhof, muzeum w Sobiborze ma ściśle dokumentalny charakter ${ }^{11}$. Zostało to już podkreślone w założeniach konkursu na projekt wystawy, w których czytamy: „z uwagi na charakter miejsca i temat wystawy jej oprawa plastyczna będzie unikać inscenizacji teatralnych, jak również środków przekazu popularnych w muzeach narracyjnych i fabularnych, które przekształcają je w «widowiska przeszłości». Tego typu performizacje i rekonstrukcje historyczne, które wprawdzie zwiększają atrakcyjność wystaw i są na ogół pozytywnie przyjmowane przez publiczność muzealną, wydają się [...] niestosowne w realnym miejscu zbrodni. Wystawa w takim miejscu nie powinna być «przestrzenią przeżyć», wykreowaną przez odtwórstwo historyczne, multimedia, efektowne środki scenograficzne i choreograficzne, ale raczej wyciszonym i powściągliwym w sposobie wyrazu miejscem informacji, refleksji i żałoby"12. Takie trzeźwe, dokumentalne podejście i niechęć do zabiegów inscenizacyjnych nie stanowią zaskoczenia, jako że głównym kuratorem wystawy jest Tomasz Kranz, bardzo dobrze zaznajomiony z niemiecką tra-

${ }^{9}$ Urbanek, Michalewicz, Mieszkowski, Projekt upamiętnienia obozu zagłady w Sobiborze..., s. 10.

${ }^{10}$ Tomasz Kranz, Wystawa stała Muzeum i Miejsca Pamięci w Sobiborze, „Varia. Magazyn/ Magazine", październik 2020 r. (numer specjalny), s. 44, http://www.sobibor-memorial.eu/ pl/news/o_wystawie_stalej_w_sobiborze_w_magazynie___varia/1392 (dostęp 6 VIII 2021 r.).

${ }^{11}$ Por. Zofia Wóycicka, Laboratorium zagłady - nowa ekspozycja historyczna na terenie obozu zagłady Kulmhof w Chełmnie nad Nerem, „Zagłada Żydów. Studia i Materiały” 2020, nr 16, s. 747-758, https://www.zagladazydow.pl/index.php/zz/article/view/659/843.

12 Ogólne założenia i struktura ekspozycji. Konkurs na opracowanie Koncepcji realizacji wystawy stałej „SS-Sondekommando Sobibor” - niemiecki obóz zagłady, Załącznik nr M3 do Regulaminu konkursu, s. 4-5, http://www.majdanek.eu/bip/konkurs_na_opracowanie_koncepcji_realizacji_wystawy_stalej__ss-sonderkommando_sobibor__niemiecki_oboz_zaglady_znak/200 (dostęp 9 VIII 2021 r.). 
dycją tworzenia wystaw historycznych poświęconych drugiej wojnie światowej i Holokaustowi ${ }^{13}$. Sztandarowym przykładem takiego podejścia są stara i nowa, otwarta w 2016 r., ekspozycja w Muzeum i Miejscu Pamięci na terenie byłego nazistowskiego obozu koncentracyjnego Buchenwald ${ }^{14}$. Podobny charakter ma również udostępniona w 2004 r. stała wystawa na terenie Muzeum i Miejsca Pamięci w Bełżcu - filii Państwowego Muzeum na Majdanku.

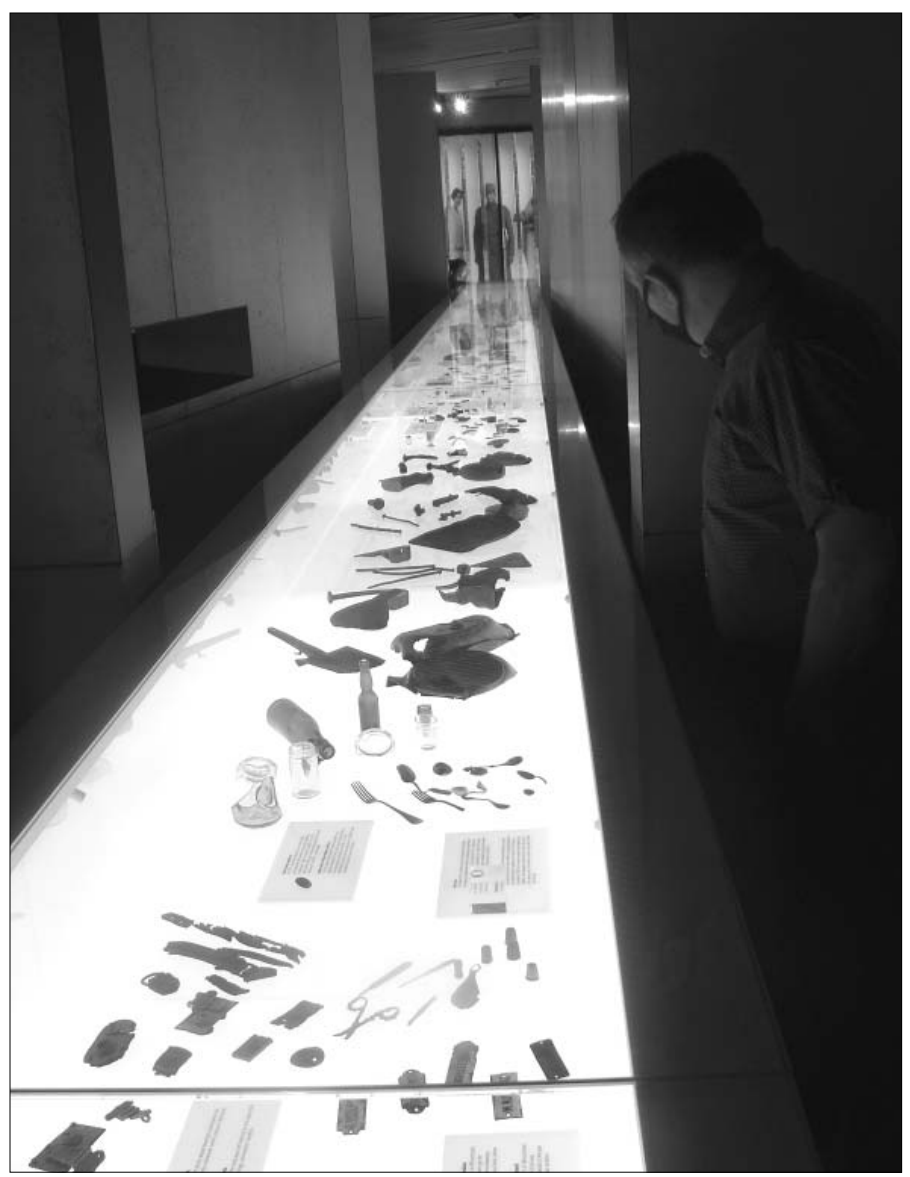

Trzon nowej ekspozycji stanowiq artefakty znalezione podczas prac archeologicznych (fot. Zofia Wóycicka)

${ }^{13}$ Niemieckie podejście do tworzenia ekspozycji historycznych poświęconych drugiej wojnie światowej było już wielokrotnie omawiane na łamach pisma „Zagłada Żydów. Studia i Materiały". Zob. m.in. Zofia Wóycicka, Wywiad z prof. Volkhardem Kniggem z okazji otwarcia w Muzeum Żydowskim w Berlinie wystawy poświęconej robotnikom przymusowym, „Zagłada Żydów. Studia i Materiały" 2012, nr 8, s. 489-504.

${ }^{14}$ Zob. m.in. Zofia Wóycicka, Buchenwald revisited, „Zagłada Żydów. Studia i Materiały” 2017, nr 13, s. 829-839, https://www.zagladazydow.pl/index.php/zz/article/view/396/419. 
Cała wystawa jest niewielka i liczy nieco ponad $320 \mathrm{~m}^{2}$. Jej centralny element stanowi pozioma, dwudziestopięciometrowa, biegnąca wzdłuż całej ekspozycji gablota, w której umieszczono przedmioty znalezione podczas prac archeologicznych. Ma ona zgodnie z założeniem projektantów nawiązywać do wyglądu stołu laboratoryjnego ${ }^{15}$. „Można w niej również - jak pisze Tomasz Kranz - doszukiwać się symboliki Schlauchu - ostatniej drogi ofiar. Idąc bowiem na śmierć, niektórzy z deportowanych gubili lub porzucali w tym miejscu kosztowności i pamiątki, które próbowali zachować do ostatniej chwili"16.

Wśród prezentowanych muzealiów znajdują się zarówno rzeczy osobiste ofiar - klucze, biżuteria, oprawki od okularów, guziki, metalowe naczynia i sztućce - jak i narzędzia zbrodni oraz rzeczy należące do sprawców, w tym łuski karabinowe, hak do usuwania ciał z komór gazowych czy fragment drutu kolczastego. Niektóre przedmioty udało się spersonalizować. Dotyczy to zwłaszcza rzeczy należących do Żydów holenderskich, słowackich oraz osób z innych krajów Europy, w przypadku których Niemcy prowadzili dokładną ewidencję transportów. Podczas prac archeologicznych na terenie obozu odnaleziono między innymi plakietkę identyfikacyjną Annie Kappler zamieszkałej przy Yselstraat 44 w Amsterdamie. Wiadomo, że w chwili deportacji miała dwanaście lat. Annie, jej sześcioletniego brata Gerarda oraz jej rodziców Elisabeth i Meijera zamordowano w Sobiborze 2 kwietnia 1943 r. Inne odnalezione przedmioty, takie jak srebrna obrączka z wygrawerowanym napisem „Wilno Ghetto 6.IX.1941 B.D." lub odznaka żydowskiego Ordnungsdienstu wykonana z holenderskiego półguldena mówią o pochodzeniu i tożsamości ofiar oraz realiach Zagłady. Część artefaktów została też umieszczona w osobnych niewielkich gablotach wmurowanych w ścianę. „W założeniu twórców ekspozycji to właśnie muzealne obiekty są podstawą budowania historycznej narracji, emocjonalnym punktem wyjścia dla wysiłku zrozumienia historii, przedmiotem wnikliwego namysłu i interpretacji, otwierającym możliwość lepszego poznania miejsca i ludzi. Rzeczy stały się tu nośnikami pamięci"17. Nadal, mimo upływu lat, przedmioty te nie straciły też wartości dowodowej.

$\mathrm{Na}$ wystawie elementy inscenizacji pojawiają się tylko w dwóch miejscach i mają raczej wstrzemięźliwy, symboliczny, a nie dosłowny charakter. Ich celem jest „budowanie nastroju” i „podkreślenie treści i przekazu” prezentacji muze-

${ }^{15}$ Konkurs na opracowanie koncepcji realizacji wystawy stałej „SS-Sonderkommando Sobibor”. Wizualizacja zwycięskiej koncepcji autorstwa Jarosława i Barbara Kłaput z „Kłaput Project” s.c., s. 1, http://www.majdanek.eu/media/photos/images/1/0/7/9/5/orig_1079587911.jpg (dostęp 5 VIII 2021 r.).

${ }^{16}$ Kranz, Wystawa stała..., s. 47.

17 SS-Sonderkommando Sobibor. Niemiecki obóz zagłady 1942-1943, Muzeum i Miejsce Pamięci w Sobiborze, 27 października 2020 r., http://www.sobibor-memorial.eu/pl/exhibitions/ss-sonderkommando_sobibor_niemiecki_oboz_zaglady_1942__1943/31 (dostęp 5 VIII 2021 r.). 
alnej $^{18}$. Stanowią one oryginalny wkład projektantów ekspozycji, którzy są też współautorami wystawy stałej Muzeum Postania Warszawskiego oraz autorami multimedialnej ekspozycji Muzeum Dom Rodzinny Ojca Św. Jana Pawła II w Wadowicach. Instalacje te nawiązują „do historycznego wyglądu obozu” i dzięki temu pozwalają również „odtworzyć wizualną pamięć miejsca”19.

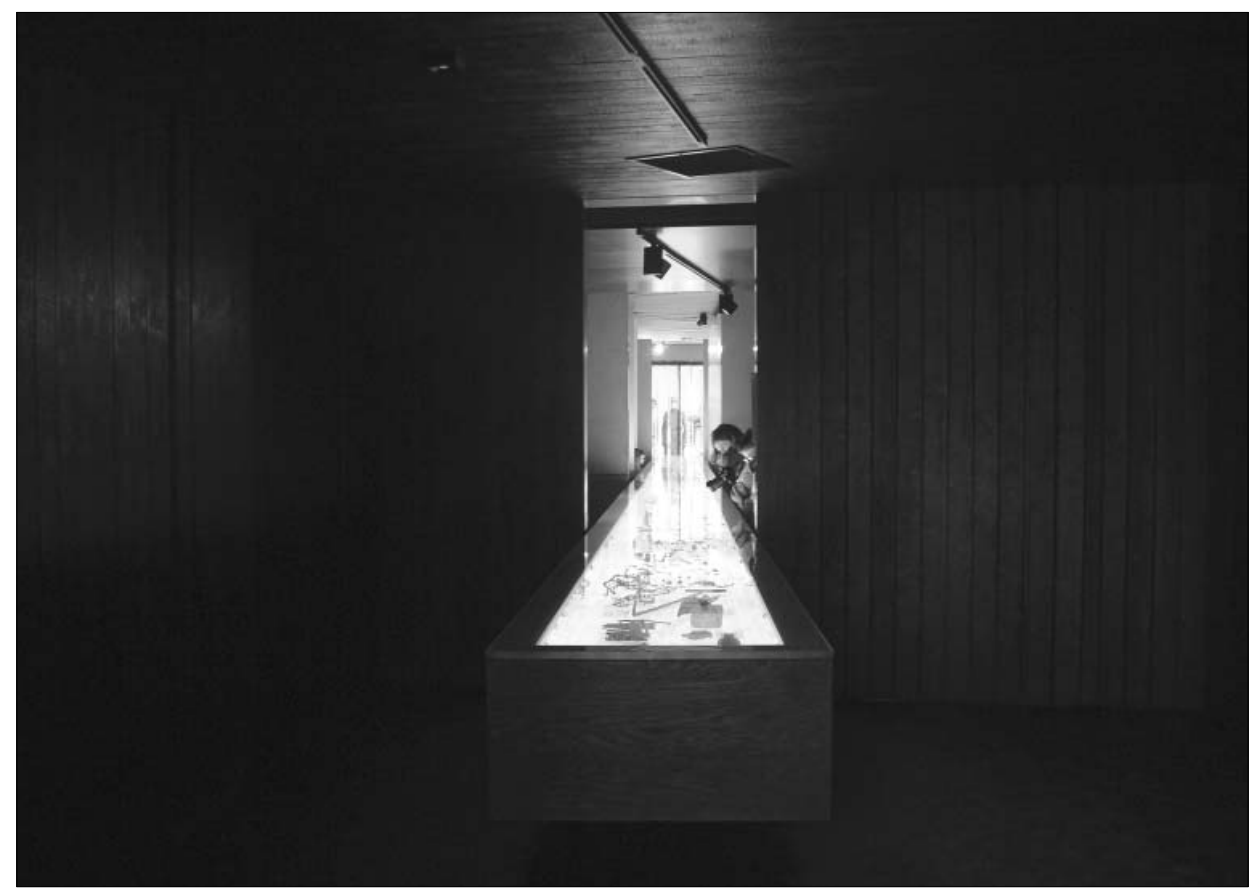

Ciemne pomieszczenie wyłożone zwęglonym drewnem przywodzi na myśl wnętrze komory gazowej lub baraku obozowego (fot. Zofia Wóycicka)

Pierwszym takim elementem jest ciemne, prostokątne wnętrze wyłożone zwęglonym drewnem, znajdujące się na końcu witryny z rzeczami po zamordowanych. Ma ono dwojaką symbolikę. Z jednej strony pomieszczenie to, sąsiadując z częścią ekspozycji poświęconą organizacji Zagłady, będzie się wielu zwiedzającym kojarzyć z komorą gazową ${ }^{20}$. Z drugiej strony przywodzi na myśl barak obozowy. Sugeruje to ulokowany w gablotce przy wejściu do tego pomieszczenia fragment oryginalnej ściany z baraku z Lager II, na którego terenie znajdowały się sortownie i magazyny mienia po pomordowanych. Naprzeciwko

\footnotetext{
${ }^{18}$ Ibidem.

${ }^{19}$ Ibidem.

${ }^{20} \mathrm{Na}$ temat symboliki tej przestrzeni zob. Konkurs na opracowanie koncepcji realizacji wystawy stałej „SS-Sonderkommando Sobibor”, s. 1; Kranz, Wystawa stała..., s. 50.
} 
wejścia umieszczono również wielkie panoramiczne okno z widokiem na teren dawnego Lager I, miejsca uwięzienia członków żydowskiego Sonderkommanda. Wnętrze to odsyła więc też zwiedzających do losu żydowskich więźniów obozu oraz ich aktywnej roli podczas powstania. Można je również postrzegać jako symboliczną instalację tworzącą przestrzeń do namysłu i kontemplacji. Drugim elementem nawiązującym bezpośrednio do wyglądu i architektury obozu jest instalacja przypominająca rampę kolejową z oryginalnym szyldem stacji Sobibór oraz wydrukowanym na blasze rysunkiem wagonu towarowego $\mathrm{w}$ tle. $\mathrm{W}$ uzmysłowieniu sobie topografii obozu pomaga także umieszczona na wystawie, odlana z czarnej żywicy makieta, powstała na podstawie świadectw historycznych i wyników badań archeologicznych.

Wokół tych centralnych elementów ekspozycji - gabloty z rzeczami po zamordowanych, rampy kolejowej, przestrzeni baraku-komory gazowej oraz makiety obozu - opowiedziane zostały na szesnastu panelach tematycznych dzieje tego miejsca podczas drugiej wojny światowej i po jej zakończeniu. Ekspozycja dzieli się na pięć części:

I. Zagłada Żydów w okupowanej przez Niemców Europie

II. Deportacje do Sobiboru

III. Obóz - organizacja i funkcjonowanie

IV. Opór więźniów i ich walka o przetrwanie

V. Miejsce zbrodni - miejsce pamięci

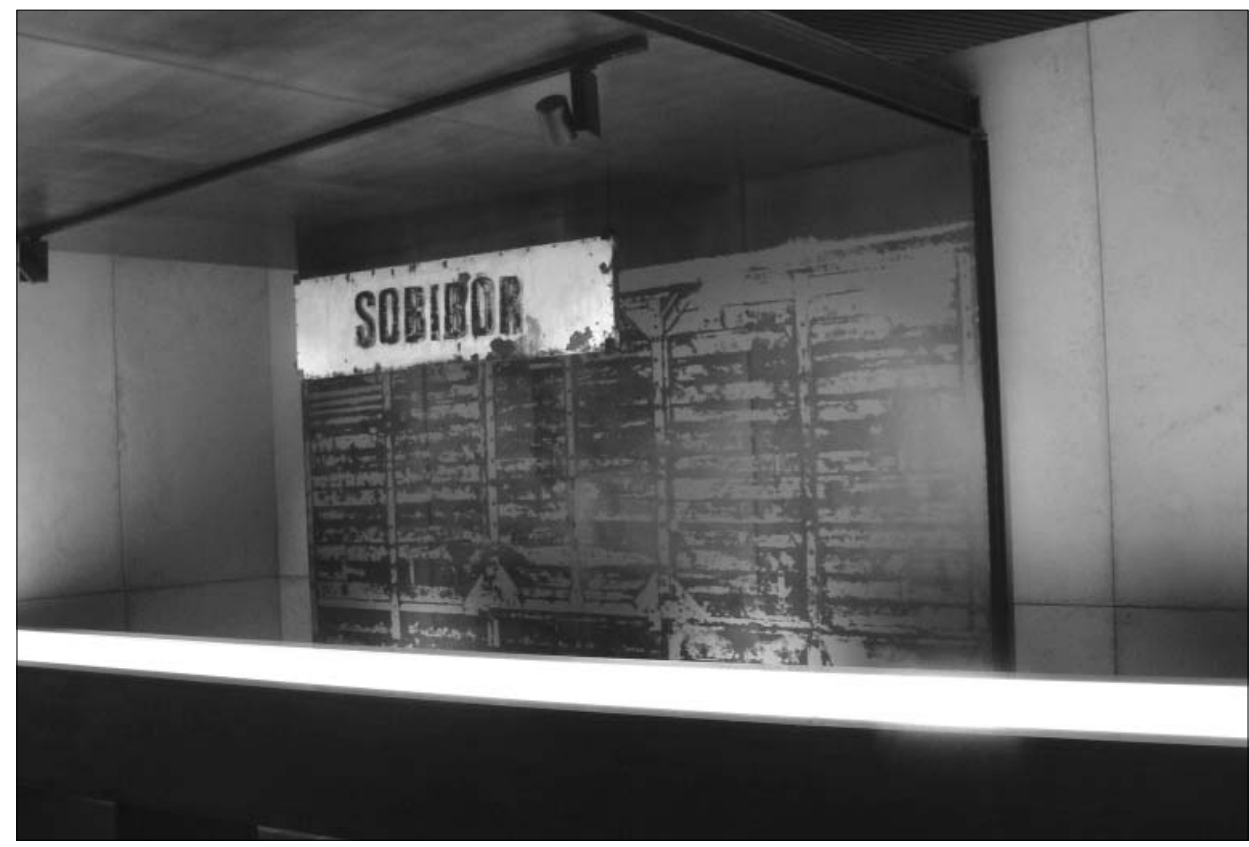

Instalacja przypominająca rampę kolejową (fot. Zofia Wóycicka) 


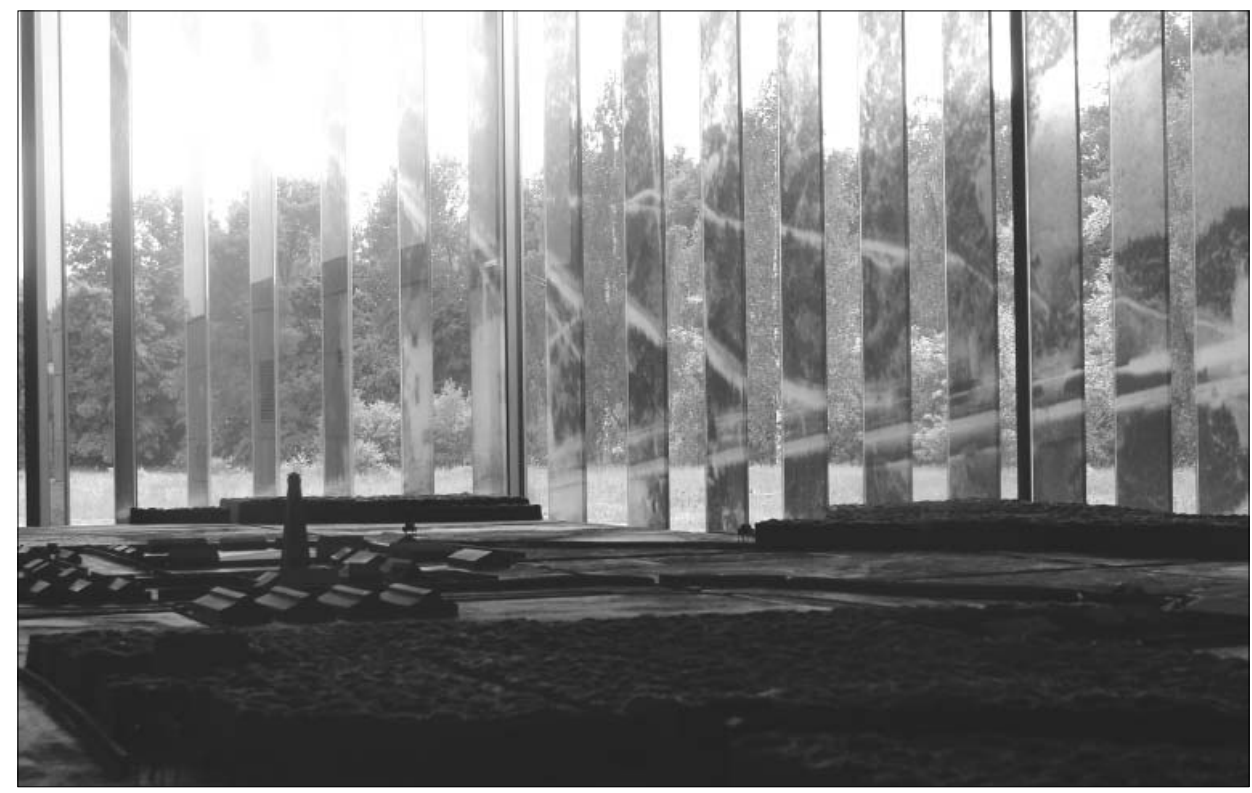

Makieta obozu powstała na podstawie świadectw historycznych i wyników badań archeologicznych (fot. Zofia Wóycicka)

Historia obozu pokazana została w szerszym kontekście niemieckiej polityki eksterminacyjnej wobec europejskich Żydów. Opisane zostało miejsce i znaczenie ośrodka w akcji „Reinhardt”, w zagładzie Żydów z okupowanej Polski, a także ze Słowacji, z Holandii oraz innych krajów Europy. Na wystawie mowa jest też o samej logistyce Zagłady, organizacji oraz funkcjonowaniu obozu, członkach załogi obozowej, jak również o żydowskich więźniach zmuszonych do pracy przy jego obsłudze, o próbach ucieczki i przebiegu powstania. Ostatni rozdział ekspozycji poświęcono powojennej historii i pamięci tego miejsca zbrodni, jego późnemu i raczej skromnemu upamiętnieniu, losom osób ocalałych z obozu oraz ich oprawców.

„Ekspozycja - jak czytamy we wstępie do katalogu - ma charakter dokumentalny, stawia więc na pierwszym planie źródła - muzealia, dokumenty, zdjęcia i świadectwa ocalałych. [...] Wystawa ogranicza się zatem do przekazu najważniejszych faktów”21. „Nie tłumaczy prezentowanych procesów i zdarzeń, raczej je relacjonuje". I rzeczywiście wystawa ma bardzo rzeczowy charakter i stroni od emocjonalizacji. Adresowana jest nie tylko do osób w szczególny sposób zainteresowanych historią, ale również do młodzieży szkolnej oraz innych zwiedzających mających nikłą wiedzę na temat drugiej wojny światowej i Holokaustu.

${ }^{21}$ Tomasz Kranz, Wstęp [w:] SS-Sonderkommando Sobibor. Niemiecki obóz zagłady 19421943. Katalog wystawy stałej, Lublin: Państwowe Muzeum na Majdanku, 2020, s. 13. 


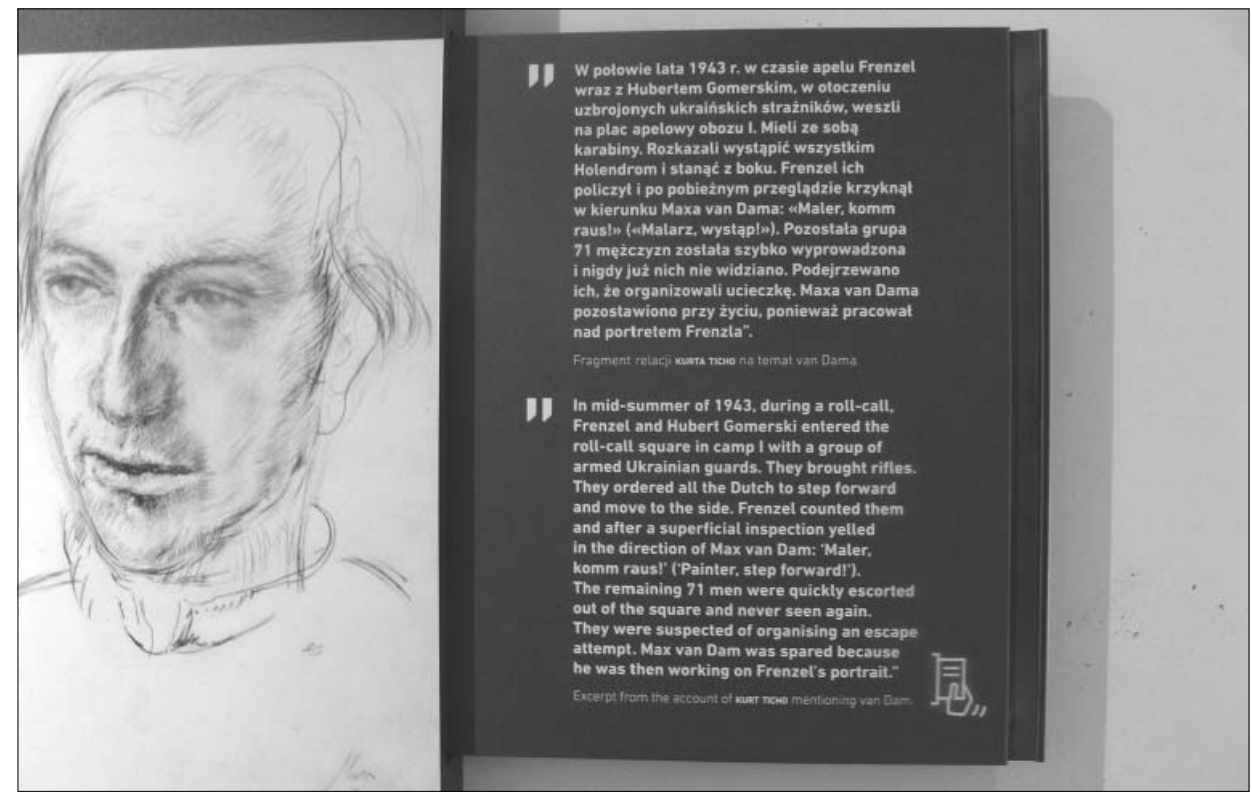

Cytaty z relacji świadków umieszczone na tabliczkach wyciaganych zza plansz ekspozycji (fot. Zofia Wóycicka)

Narrację prowadzą komentarze kuratorskie. Teksty główne zostały uzupełnione rozbudowanymi podpisami pod materiałem fotograficznym i kopiami dokumentów. Zgodnie z deklaracją autorów ekspozycji, materiały te nie mają stanowić jedynie ilustracji informacji zawartych w leadach, lecz mają opowiadać osobne mikrohistorie $^{22}$. Relacje świadków zajmują na wystawie raczej miejsce drugoplanowe, co wyraża się już w samym ich usytuowaniu - większość z nich umieszczono na tabliczkach wyciąganych zza głównych tablic ekspozycji. Wybrane cytaty są rzeczowe, mówią o faktach i oddają obserwacje świadków, a nie ich uczucia. Traktowane są więc jako materiał dowodowy i ilustracja ustaleń historyków. Znamienne jest, że nagrania filmowe z relacjami osób, które przeżyły Sobibór, pochodzące ze zbiorów Shoah Foundation Stevena Spielberga, znalazły się nie w części historycznej ekspozycji, ale w rozdziale poświęconym pamięci i upamiętnieniu tego miejsca.

Pod tym względem wystawa w Sobiborze idzie pod prąd aktualnych trendów muzealniczych. W wielu współczesnych muzeach i miejscach pamięci, zwłaszcza tych poświęconych pierwszej i drugiej wojnie światowej oraz Holokaustowi, świadectwom indywidualnym przypisuje się bardzo istotne, jeżeli nie centralne miejsce na ekspozycji. Niestety, niekiedy relacje te traktowane są przez kuratorów wystaw w sposób bezkrytyczny i przytaczane bez komentarza, niemal jako prawda objawiona.

\footnotetext{
${ }^{22}$ Kranz, Wystawa stała..., s. 46.
} 


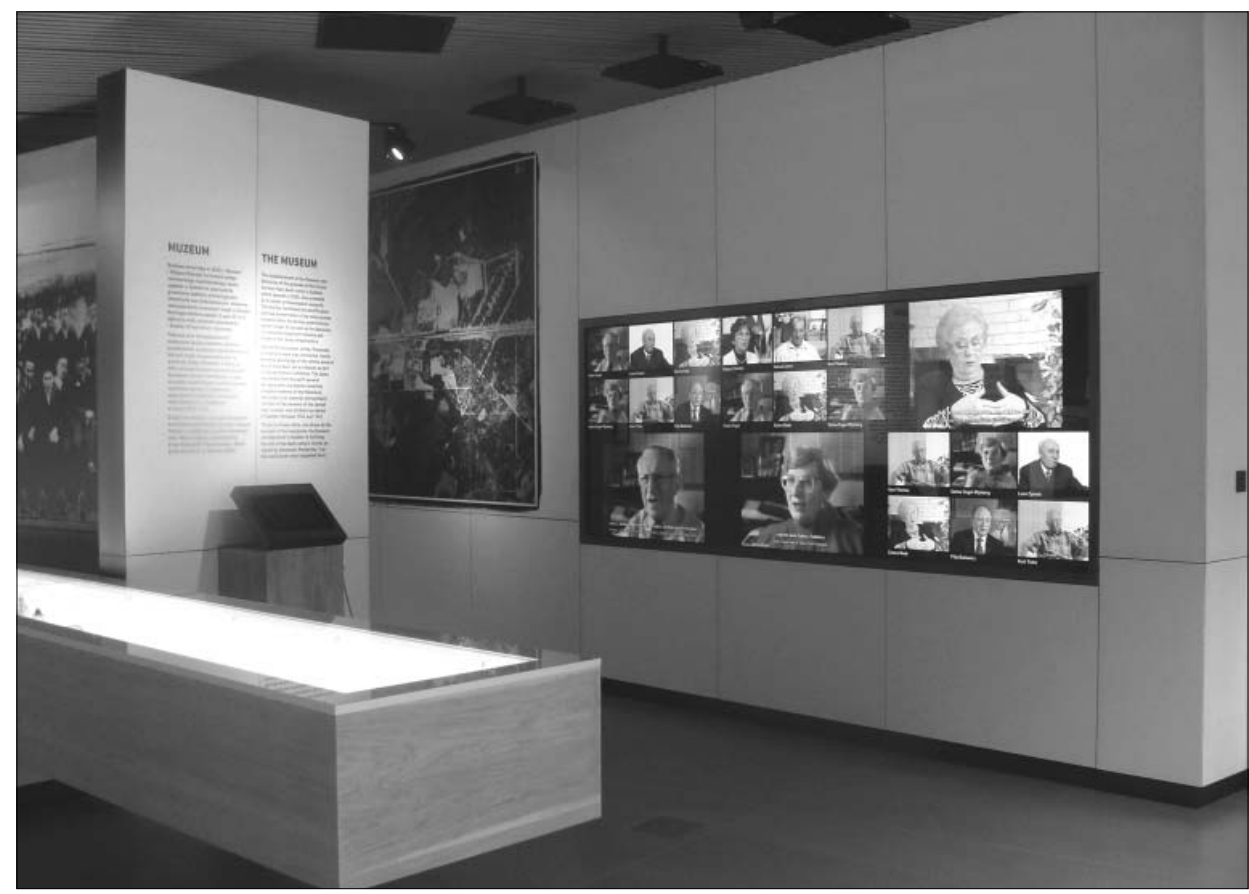

Końcowa sala ekspozycji, w której umieszczono nagrania filmowe z relacjami osób ocalałych z Sobiboru (fot. Zofia Wóycicka)

W Sobiborze relacjom osobistym przypisano skromniejsze miejsce. Nie świadczy to bynajmniej o braku szacunku dla ofiar lub o chęci podważenia ich wiarygodności jako świadków. Wręcz przeciwnie, za pośrednictwem zdjęć i artefaktów ekspozycja przywraca pamięć o indywidualnych osobach, ofiarach obozu i uczestnikach powstania. Autorzy scenariusza są jednak wyraźnie zwolennikami bardziej pozytywistycznego podejściu do świadectw historycznych. Zdają się mówić: relacje świadków, tak samo jak wszystkie inne źródła historyczne, muszą podlegać krytycznej analizie. Muszą zostać poddane ocenia historyka, zinterpretowane i umieszczone we właściwym kontekście. Surowe, nieopracowane relacje, zwłaszcza takie, które powstały wiele lat po wojnie, należą raczej do domeny pamięci, a nie historii.

Tylko w jednym miejscu sposób prezentowania relacji osobistych sugeruje bardziej intymną więź między świadkami historii i zwiedzającymi. W części wystawy poświęconej oporowi więźniów i ich walce o przetrwanie umieszczono cztery głośniki w formie czarnych rur ze stali nierdzewnej zwieszonych z sufitu. Dopiero po ich dotknięciu z głośników wydobywa się nagranie wspomnień.

Niewielka przestrzeń ekspozycji zmusiła projektantów do umieszczenia części wiadomości w formie multimediów. Odnosi się to przede wszystkim do informacji dotyczących dat, tras i pochodzenia transportów deportacyjnych kiero- 
wanych do Sobiboru z różnych stron Europy. W pozostałych częściach wystawy starano się jednak raczej oszczędnie posługiwać nowoczesną techniką.

Na szczególną uwagę zasługuje część ekspozycji poświęcona sprawcom. Mowa tu nie tylko o przywódcach nazistowskich, Adolfie Hitlerze, Reichsführerze SS Heinrichu Himmlerze czy Odilu Globocniku, szefie SS i policji w dystrykcie lubelskim i głównym odpowiedzialnym za realizację planu eksterminacji Żydów w Generalnym Gubernatorstwie, ale również o „zwykłych ludziach”, niemieckich członkach załogi obozowej ${ }^{23}$. Na wystawie mowa o ich profilu społecznym, udziale w zbrodni, a także o życiu codziennym w cieniu Zagłady. Stanowi to nawiązanie do współczesnych trendów w edukacji o Holokauście i drugiej wojnie światowej, w tym również w muzealnictwie. Choć biografie i świadectwa ofiar pozostają nadal bardzo ważne, coraz częściej podkreśla się potrzebę zwrócenia uwagi na konkretnych sprawców, ich biografie, motywacje oraz na dynamikę eskalacji zbrodni i przemocy ${ }^{24}$. Nie chodzi tu bynajmniej o usprawiedliwienie sprawców. Wręcz przeciwnie, propagatorzy nowego podejścia zwracają uwagę, że skupienie wyłącznie na ofiarach i ich cierpieniu skutkuje zbyt łatwym utożsamianiem się odbiorców z ofiarami i tym samym utrudnia pogłębioną refleksję nad mechanizmami zbrodni. W podobnym kierunku zmierza również otwarta w 2020 r. na terenie Muzeum i Miejsca Pamięci Ravensbrück wystawa "«Im Gefolge der SS» - Aufseherinnen des Frauen-Konzentrationslagers Ravensbrück" [W służbie SS - Aufzejerki obozu koncentracyjnego dla kobiet Ravensbrück] ${ }^{25}$.

Ogromne wrażenie robią nieznane dotąd fotografie wykonane przez zastępcę komendanta obozu Johanna Niemanna. Dopiero w 2015 r. zbiór ponad 300 zdjęć z okresu jego służby w ramach programu eutanazji (tzw. akcja T4) oraz w obozach zagłady w Bełżcu i Sobiborze został przekazany przez jego wnuka niemieckiemu Bildungswerk Stanislaw Hantz. Dodatkowe fotografie tego samego autorstwa zostały znalezione w 2019 r. W 2020 r. kolekcję zakupiło waszyngtońskie United States Holocaust Memorial Museum ${ }^{26}$. Około 50 zdjęć z tej kolekcji pochodzi z Sobiboru. Ukazują one m.in. wybudowane w rustykalnym stylu, drewniane, pomalowane na biało kwatery mieszkalne i budynki użytkowane przez SS, w tym kasyno, pralnię oraz łaźnię, a także członków załogi SS odpoczywających przy piwie i innych trunkach na dziedzińcu Vorlager. Konfrontacja

${ }^{23}$ Christopher R. Browning, Zwykli ludzie. 101. Rezerwowy Batalion Policji i „ostateczne rozwiqzanie" w Polsce, tłum. Piotr Budkiewicz, Poznań: Rebis, 2019.

${ }^{24}$ Zob. m.in. Jan Eckel, Claudia Moisel, Einleitung [w:] Universalisierung des Holocaust? Erinnerungskultur und Geschichtspolitik in internationaler Perspektive. Beiträge zur Geschichte des Nationalsozialismus 24, red. Jan Eckel, Claudia Moisel, Göttingen: Wallenstein Verlag, 2008, s. 9-25.

${ }^{25}$ https://www.ravensbrueck-sbg.de/ausstellungen/dauerausstellungen/im-gefolge-der-ss-aufseherinnen-des-frauen-konzentrationslagers-ravensbrueck/ (dostęp 9 VIII 2021 r.).

${ }^{26}$ Museum Acquires Sobibor Perpetrator's Collection, USHMM, 28 stycznia 2020 r., https:// www.ushmm.org/information/press/press-releases/sobibor-perpetrator-collection (dostęp 9 VIII 2021 r.). 
tych sielankowych obrazków z wiedzą o tym, co się działo w tym samym czasie zaledwie kilkadziesiąt metrów dalej, jest szokująca i wiele mówi o mentalności sprawców. Mniej uwagi autorzy scenariusza wystawy poświęcili członkom formacji wartowniczej z Trawnik. Byli to dawni sowieccy jeńcy wojenni, głównie Ukraińcy, którym w zamian za służbę w SS darowano życie. Innym bardzo ciekawym, a dotychczas nigdy nieprezentowanym lub pokazywanym rzadko materiałem są kopie rysunków Józefa Richtera, polskiego Żyda ukrywającego się na „aryjskich” papierach, przedstawiające transporty Żydów do Sobiboru. Seria 18 rysunków wykonanych ołówkiem na skrawkach gazet została odnaleziona w okolicach Chełma i znajduje się obecnie w zbiorach Domu Bojowników Gett w Izraelu.

Na szacunek zasługują również ogromne poczucie odpowiedzialności, z jaką autorzy scenariusza formułowali teksty na wystawę, i precyzja w określaniu zakresu odpowiedzialności poszczególnych grup, poczynając od przywódców Trzeciej Rzeszy, przez niemieckich funkcjonariuszy policji i żandarmów, przedstawicieli niemieckich władz cywilnych i członków obozowej SS, po tzw. Trawnikimänner. Mowa też o wciągnięciu w proces eksterminacji kolei krajów okupowanych i sprzymierzonych z Trzecią Rzeszą. W tym wspomniano również o zatrudnionych w podporządkowanej kolejom niemieckim Kolei Wschodniej (Ostbahn) Polakach i o polskich drużynach przewozowych, które prowadziły „Pociągi specjalne” wiozące Żydów do obozów zagłady. Mowa też o członkach Policji Polskiej (tzw. granatowej) oraz policji ukraińskiej, którzy - jak potwierdzają to najnowsze badania - pod niemiecką komendą nierzadko uczestniczyli w łapankach i akcjach deportacyjnych Żydów na terenach $\mathrm{GG}^{27}$. Omawiając losy uciekinierów z obozu - z około 300 powstańców końca wojny dożyło jedynie 60 osób - wspomniano, że podczas gdy niektórzy z nich przeżyli dzięki pomocy miejscowych Polaków i Ukraińców, inni padli ofiarą lokalnej ludności i partyzantów. W części dotyczącej powojennej historii obozu wspomniano też, choć bardzo krótko, o rozkopywaniu terenu obozu w poszukiwaniu kosztowności, co zdarzało się aż do lat osiemdziesiątych ${ }^{28}$.

Duże wrażenie robią również prezentowane na ekspozycji ślady, które historia tego miejsca pozostawiła w przyrodzie, nadal widoczne przy jej dokładnym czytaniu. Na wystawie zobaczyć można np. pnie drzew wewnątrz z drutem kolczastym, którym ogrodzony był teren obozu, oraz korzeń drzewa wrośnięty w nożyczki. Nawiązuje to do rozwijającej się dziedziny badań nad środowiskową historią Holokaustu, choć w tym przypadku chodzi chyba przede wszystkim

\footnotetext{
${ }^{27}$ Szerzej na ten temat: Jan Grabowski, Na posterunku. Udział polskiej policji granatowej i kryminalnej w zagładzie Żydów, Wołowiec: Czarne, 2020.

${ }^{28}$ Szerzej na ten temat: Paweł Piotr Reszka, Płuczki. Poszukiwacze żydowskiego złota, Warszawa: Agora, 2019.
} 
o uwrażliwienie zwiedzających na znaki przeszłości obecne w przyrodzie ${ }^{29}$. Zgodnie z deklaracją autorów ekspozycji, odgrywa ona „rolę służebną wobec miejsca historycznego. Ma zachęcać odwiedzających do jego poznawania, kontemplacji i interpretacji - innymi słowy do czytania zastanego krajobrazu"30.

Póki jednak teren dawnego obozu nie zostanie uporządkowany i opisany, dla większości osób pozostanie nieczytelny. Dokończenie prac nad nową koncepcją upamiętnienia obozu stanowić więc będzie konieczne uzupełnienie powstałej już, bardzo ciekawej, podążającej za najnowszymi trendami wystawienniczymi i oddającej aktualny stan badań, a równocześnie zachowującej decorum, ekspozycji muzealnej.

\section{BIBLIOGRAFIA}

Browning R. Christopher, Zwykli ludzie. 101. Rezerwowy Batalion Policji i „ostateczne rozwiązanie” w Polsce, tłum. Piotr Budkiewicz, Poznań: Rebis, 2019.

Eckel Jan, Moisel Claudia, Einleitung [w:] Universalisierung des Holocaust? Erinnerungskultur und Geschichtspolitik in internationaler Perspektive. Beiträge zur Geschichte des Nationalsozialismus 24, red. Jan Eckel, Claudia Moisel, Göttingen: Wallenstein Verlag, 2008.

Grabowski Jan, Na posterunku. Udział polskiej policji granatowej i kryminalnej w zagładzie Żydów, Wołowiec: Czarne, 2020.

„Im Gefolge der SS” - Aufseherinnen des Frauen-Konzentrationslagers Ravensbrück, https://www.ravensbrueck-sbg.de/ausstellungen/dauerausstellungen/im-gefolge-der-ss-aufseherinnen-des-frauen-konzentrationslagers-ravensbrueck/.

Konkurs na opracowanie koncepcji realizacji wystawy stałej „SS-Sonderkommando Sobibor". Wizualizacja zwycięskiej koncepcji autorstwa Jarosława i Barbara Kłaput $Z$ „Kłaput Project” s.c.,. http://www.majdanek.eu/media/photos/images/1/0/7/9/5/orig_1079587911.jpg.

Kranz Tomasz, Upamiętnienie pomordowanych. Pomnik z 1965 r. w hołdzie ofiarom obo$z u$, „Varia. Magazyn/Magazine”, październik 2020 r. (numer specjalny), http:// www.sobibor-memorial.eu/pl/news/o_wystawie_stalej_w_sobiborze_w_magazynie__varia/1392.

Kranz Tomasz, Wystawa stała Muzeum i Miejsca Pamięci w Sobiborze, „Varia. Magazyn/ Magazine”, październik 2020 r. (numer specjalny), http://www.sobibor-memorial.eu/pl/news/o_wystawie_stalej_w_sobiborze_w_magazynie__varia/1392.

Kranz Tomasz, Wstęp [w:] SS-Sonderkommando Sobibor. Niemiecki obóz zagłady 19421943. Katalog wystawy stałej, Lublin: Państwowe Muzeum na Majdanku, 2020.

Małczyński Jacek, Historia środowiskowa Zagłady, „Teksty Drugie” 2017, nr 2.

Memorandum of Understanding with regard to a collective project on to establish a Museum-Memorial Site within the area of the former Nazi German extermination camp Sobibor, 28 lutego 2011 r., https://archiv.vlada.gov.sk/ludskeprava/data/ files/7401.pdf.

${ }^{29}$ Zob. m.in. Jacek Małczyński, Historia środowiskowa Zagłady, „Teksty Drugie” 2017, nr 2, s. 17-33.

${ }^{30} \mathrm{Kranz}$, Wystawa stała..., s. 50. 
Michalkiewicz \& Co. Architects, Muzeum oraz miejsce pamięci ofiar na terenie byłego nazistowskiego obozu zagłady, woj. lubelskie, 2013. http://www.michalewicz.co/ Sobibor-commemoration.

Museum Acquires Sobibor Perpetrator's Collection, USHMM, 28 stycznia 2020 r., https://www. ushmm.org/information/press/press-releases/sobibor-perpetrator-collection.

Ogólne założenia i struktura ekspozycji. Konkurs na opracowanie Koncepcji realizacji wystawy stałej „SS-Sondekommando Sobibor” - niemiecki obóz zagłady, Załącznik nr M3 do Regulaminu konkursu, http://www.majdanek.eu/bip/konkurs_na_opracowanie_koncepcji_realizacji_wystawy_stalej____ss-sonderkommando_sobibor__niemiecki_oboz_zaglady_znak/200.

Reszka Paweł Piotr, Płuczki. Poszukiwacze żydowskiego złota, Warszawa: Agora, 2019.

Rozstrzygnęliśmy konkurs na opracowanie koncepcji realizacji aranżacji plastycznej wystawy stałej w Sobiborze, Państwowe Muzeum na Majdanku, 20 maja 2019 r., http://www.majdanek.eu/pl/news/rozstrzygnelismy_konkurs_na_opracowanie_koncepcji_realizacji_aranzacji/1071.

Sendyka Roma, Miejsca/nie-miejsca pamięci [w:] Nie-miejsca pamięci. Elementarz, red. Karina Jarzyńska, Maria Kobielska, Jakub Muchowski, Roma Sendyka, Aleksandra Szczepan, Kraków: Ośrodek Badań nad Kulturami Pamięci, 2017, https://ruj. uj.edu.pl/xmlui/bitstream/handle/item/49688/jarzynska_kobielska_muchowski_sendyka_szczepan_nie-miejsca_pamieci_elementarz_2017.pdf?sequence$=1 \&$ isAllowed $=$.

Shalev Avner, Słowo od członków Międzynarodowego Komitetu Sterującego, „Varia. Magazyn/Magazine”, październik 2020 r. (numer specjalny), http://www.sobibor-memorial.eu/pl/news/o_wystawie_stalej_w_sobiborze_w_magazynie__varia/1392.

Sobibór - archeologia pamięci, Muzeum i Miejsce Pamięci w Sobiborze, 7 czerwca 2013 r., http://www.sobibor-memorial.eu/pl/news/sobibor archeologia_pamieci/397.

Sobibór Gedenksteine, Miejsce pamięci, https://sobibor.de/pl/miejsce-pamieci.

SS-Sonderkommando Sobibor. Niemiecki obóz zagłady 1942-1943, Muzeum i Miejsce Pamięci w Sobiborze, 27 października 2020 r., http://www.sobibor-memorial.eu/pl/exhibitions/ss-sonderkommando_sobibor_niemiecki_oboz_zaglady_1942_1943/31.

Szymula Aleksandra, Muzealia sobiborskie. Przedmioty znalezione w miejscu zbrodni, „Varia. Magazyn/Magazine”, październik 2020 r. (numer specjalny), http://www.sobibor-memorial.eu/pl/news/o_wystawie_stalej_w_sobiborze_w_magazynie varia/1392.

Urbanek Marcin, Michalewicz Piotr (Biuro Architektoniczne RE: Michalewicz \& Tański) oraz Mieszkowski Łukasz, Projekt upamiętnienia obozu zagłady w Sobiborze. I nagroda w Międzynarodowym Konkursie na opracowanie ideowo-artystycznej koncepcji architektoniczno-krajobrazowej miejsca pamięci na terenie Byłego Hitlerowskiego Obozu Zagłady w Sobiborze, https://www.polin.pl/template/gfx/ sobibor.pdf.

Wóycicka Zofia, Wywiad z prof. Volkhardem Kniggem z okazji otwarcia w Muzeum Żydowskim w Berlinie wystawy poświęconej robotnikom przymusowym, „Zagłada Żydów. Studia i Materiały" 2012, nr 8.

Wóycicka Zofia, Buchenwald revisited, „Zagłada Żydów. Studia i Materiały” 2017, nr 13, https://www.zagladazydow.pl/index.php/zz/article/view/396/419.

Wóycicka Zofia, Laboratorium zagłady - nowa ekspozycja historyczna na terenie obozu zagłady Kulmhof w Chełmnie nad Nerem, „Zagłada Żydów. Studia i Materiały” 2020, nr 16, https://www.zagladazydow.pl/index.php/zz/article/view/659/843. 